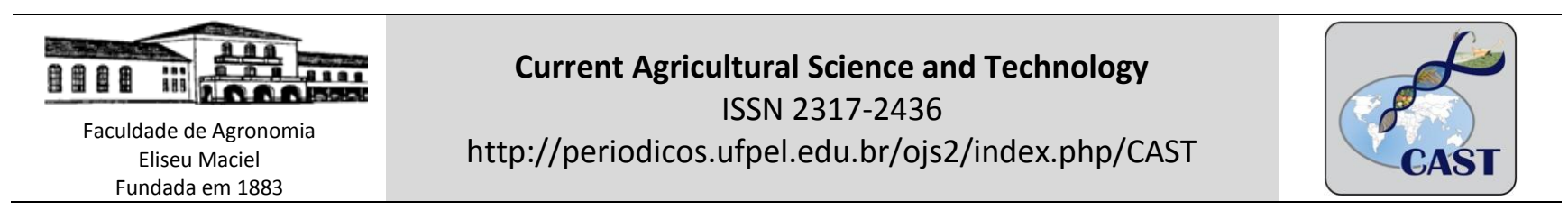

\title{
Defoliation at different vegetative stages and assessment of morphological and yield components of soybean
}

\author{
Maicon Nardino ${ }^{1 *}$, Velci Queiróz de Souza ${ }^{1}$, Carlos André Bahry $^{2}$, Ivan Ricardo Carvalho ${ }^{1}$, \\ Braulio Otomar Caron ${ }^{1}$, Paulo Dejalma Zimmer ${ }^{2}$, Carlos Busanello $^{7}$
}

\footnotetext{
${ }^{1}$ Universidade Federal de Santa Maria, BR 386, km 40, Linha 7 de Setembro, 98.400-000, Frederico Westphalen, Rio Grande do Sul, Brazil. (55) 9965-4198.

${ }^{2}$ Universidade Federal de Pelotas. Faculdade Agronomia Eliseu Maciel, 96010-610, Capão do Leão, Rio Grande do Sul, Brazil.

*Corresponding author: M. Nardino

E-mail: nardinomn@gmail.com
}

\section{ABSTRACT}

Our objective was to evaluate the influence of defoliation at different vegetative stages on morphological characters and yield components of an indeterminate soybean cultivar. The study was conducted in 2010/11 and 2011/12. The experimental design was a randomized block design with seven treatments and four replications for each year. The treatments were: T1: No defoliation; T2: Defoliation in V4, T3: Defoliation in V4 and V5, T4: Defoliation in V4, V5 and V6, T5: Defoliation in V4, V5, V6 and V7, T6: Defoliation in V4, V5, V6, V7 and V8 and T7: Defoliation in V4, V5, V6, V7, V8 and V9. Defoliation was simulated artificially, in specified periods where we proceeded to remove all leaves from each node including the petiole. The variables analyzed were: main stem height, number and length of branches, first pod, number of pods per node on the main stem, and the branches per plant, number of reproductive nodes on the main stem, the branches, number of us total on the main stem, the branches, distance between us and grain yield. Grazing did not influence most of the morphological characters and increments the number of pods on the stem in years with good water availability and high levels of defoliation, and of soybean yield.

Keywords: defoliation, plant development, morphology, Glycine max L.

\section{INTRODUCTION}

Soybeans are a major commodity in the world and one of the most important export products from Brazil. In the agricultural year 2011/2012 soybeans were cultivated in more than 25 million hectares of Brazil and national production was approximately 66.4 million tons (Conab, 2012).

The ability of soybeans to prevent substantial reduction in yield after the loss of leaves caused by defoliators and disease depends on several factors among including intensity of, the phenological stage of development at the time of defoliation, duration of defoliation, the ability of cultivar to tolerate or compensate for defoliation, and environmental conditions, especially rainfall, temperature and solar radiation (Pedigo et al., 1986; Parcianello et al., 2004). Regarding the percentage of defoliation, research has established levels for the control of insect pests, when the defoliation are greater than $30 \%$ in the vegetative phase, or $15 \%$ in the 
reproductive ph ase. However, these recommendations are based on work done in the 70-80's decades (Fontoura et al., 2006). In this sense, another key issue for reduction of income is the degree to which defoliation reduces light interception by the canopy (Higley, 1992).

The loss of leaf area during the reproductive stages is more harmful than during the vegetative stages, with the emergence and development of more sinks (reproductive structures) at this stage, which require a greater amount of photoassimilates for maintenance (Sediyama et al., 1996). So, most studies that evaluate the effects of defoliation in soybeans exclusively during the reproductive period (Barros et al., 2002; Costa et al., 2003). However, there are few studies that quantify the effects and establish tolerance limits of defoliation at different stages of the growing season on yield components and other morphological characters of agronomic interest.

Furthermore, most studies evaluating defoliation used determinant cultivars (Ribeiro and Costa, 2000); (Peluzio et al., 2004); (Diogo et al., 1997); however, the current trend is for the development of cultivars with indeterminate growth (Mundstock and Thomas, 2005), which are potentially more productive. Also, it is important to assess the impact of biotic stresses in various climatic conditions by evaluating whether the environment is aggravates or relieves losses from pests. Based on the above, the study reported here evaluates the influence of defoliation of a soybean plant with indeterminate growth in different vegetative stages on morphological characters and yield components.

\section{MATERIAL AND METHODS}

The present work was conducted on soil classified as Latosol Alumino-Ferric. The climate is Cfa type according to Köppen, subtropical. The conduct of the study occurred in two crop years 2010/2011 and 2011/2012. The indeterminate soybean cultivar 'Roos Camino RR' (very early, maturity group 5.3) was used in both years. The experimental area was demarcated within a field managed with applications of insecticides and fungicides in a preventative manner. The products used were: Priori Xtra and Methamidophos, applied every 20 days.

The experimental design used was a randomized block design with seven treatments and four replications, totaling 28 experimental units for each year, allocated in a two factorial ( 7 treatments $\times 2$ agricultural harvests). Each plot consisted of four lines of sowing three meters long, spaced $0.45 \mathrm{~m}$. The seeding density was 330,000 plants ha- ${ }^{1}$. The sowing was carried on October 15 for the 2010/2011, and October 20 for 2011/2012 season. Defoliation was simulated artificially in a manual way, in specified periods we proceeded to remove all leaves from each node including the petiole.

The identification of development stages was based on the description of Fehr and Caviness (1977). The stage classification of soybean development proposed by the authors accurately identifies the stage of development of plant of soybean. There were the following leaf removal treatments have followed leaf removal treatments for: T1: no defoliation, T2: withdrawn the pair of unifoliate leaf the V4 stage of this and the other treatments (T3, T4, T5, T6, T7), T3: removed the first trifoliate at $\mathrm{V} 5$, this and the remainder (T4, T5, T6, T7), T4: withdrawn the second trefoil in V6, this and (T6 and T7), T5: detached in the third trefoil V7, and this treatment (T6 and T7) T6: detached in the fourth trefoil stage V8 T6 and T7, T7: this latest treatment consisted in the withdrawal of the fifth trefoil stadium in V9.

For the sampling, $0.5 \mathrm{~m}$ at the ends of the lines and the two lateral lines of each experimental unit were avoided to minimize potential effect of the edges. Ten plants of each plot were harvested. The variables analyzed were: Height of main stem (HS): Distance between the ground level to the apex of the main stem in centimeters; Number of branches (NB): Count of all branches of plants per replication and divided by the number of plants sampled; Length of 
branches (LB): Measure the distance between the insertion of the stem secondary on the main stem to the apex of the stem secondary, all branches of the plants evaluated, the measures were summed and divided by the number of branches in centimeters: First pod insertion on the main stem (LPN): determined by the distance between the ground level and first pod insertion on the main stem in centimeters; Number main stain pods (MSP): summation of pods on the main stem; Number of branch pods (BP): sum total pods in branches; Number of pods per plant (TP): sum of the number of pods on the main stem and branches of each plant; Reproductive number of nodes on the main stem (RNMS): total nodes that had at least one pod with grain inserted on the main stem; Number of nodes in reproductive branches (NRB): total nodes that had at least one pod with grain inserted in the branches; Total number of nodes on the main stem (NMS): total nodes on the main stem; Total number of nodes in the branches (NNB): total nodes in the branches; Number of pods per node (NPN): pods number divided by total number of nodes; Distance between nodes (DBN): distance between nodes on the main stem in centimeters; Grain Yield: adjusted to $13 \%$ moisture, transformed to hectare, $\mathrm{kg} \mathrm{ha}^{-1}$.

The results obtained for the two agricultural harvests were submitted to Analysis of Variance. Where significant interactions were not observed, treatment separations were made using a Tukey's test at 5\% probability.

\section{RESULTS AND DISCUSSION}

The analysis of variance did not reveal significant interactions for the variables height of first pod insertion (LPN), number of pods on branches (BP), number of pod per node (NPN), number of reproductive nodes on the main stem (RNMS), the branches (NRB), number of nodes on the stem (NMS), the branches, internodes distance (DBN) and number of pods per plant
(TP). Interaction, which were analyzed separately for factor treatment (Table 1).

The analysis of variance revealed significant effects for interaction treatment $x$ growing seasons for the variables stem height (HS), number of branches (NB), length of branches (LB), number of pod on the main stem (MSP), and yield grains, demonstrating that the response to defoliation fluctuates with the timing of defoliation (Table 2).

For these variables, only the number of pods per plant was also significant for defoliation treatments. The treatment 7 with greater intensity had the greatest number of pods per plant compared to treatment 2, but did not differ from control without defoliation. None of the other treatments differed from the control without defoliation indicating no effect of defoliation on the number of pods per plant. This is not consistent with results of Diogo et al. (1997), which demonstrated an increase of up to $82.76 \%$ in the number of pods and defoliation of $33 \%$ and $66 \%$ for stage V9, and other stages, or of Parcianello et al. (2004), who demonstrated that there was a beneficial effect of removing leaf area in stage V9 on the number of pods per $\mathrm{m}^{2}$ at various levels of defoliation. The authors attributed these results to the increased incidence of light in the canopy that allowed greater fixing pods. In this study there was no increase in the number of pods compared to control, but the levels of defoliation did not reduce the pods in the plant, mainly due occur higher incidence and light penetration within the canopy. These results also do not agree with Reichert and Costa (2003), who found all defoliation treatments reducing the number of normal pods. Stress by defoliation in V4 has negative effects on the number of pods per plant, occurs in the early stages of the plants more sensitive to stress and damage caused by defoliation at this stage provides an important component to reducing soybean yield. 
Table 1. Average results obtained for the treatments to first pod insertion (LPN), number of pod on branches (BP), number of pod per node (NPN), number of reproductive nodes on the main stem (RNMS), number of nodes reproductive branches (NRB), total number of nodes on the stem (NMS), total number of nodes the branches (NNB), distance between nodes (DBN) and number of pods per plant (TP), in soybean, Frederico Westphalen, seasons 2010 / 2011 and 2011/2012.

\begin{tabular}{clllllllll}
\hline Treatment & LPN & BP & NPN & RNMS & NRB & NMS & NNB & DBN & TP \\
\hline $1^{*}$ & $10.307 \mathrm{a}$ & $5.3 \mathrm{a}$ & $2.48 \mathrm{a}$ & $9.44 \mathrm{a}$ & $2.77 \mathrm{a}$ & $12.45 \mathrm{a}$ & $3.11 \mathrm{a}$ & $4.62 \mathrm{a}$ & $31.32 \mathrm{ab}$ \\
2 & $9.923 \mathrm{a}$ & $4.46 \mathrm{a}$ & $2.4 \mathrm{a}$ & $10.07 \mathrm{a}$ & $2.12 \mathrm{a}$ & $13.16 \mathrm{a}$ & $2.12 \mathrm{a}$ & $4.51 \mathrm{a}$ & $29.91 \mathrm{~b}$ \\
3 & $11.447 \mathrm{a}$ & $7.35 \mathrm{a}$ & $2.67 \mathrm{a}$ & $9.54 \mathrm{a}$ & $2.21 \mathrm{a}$ & $13.18 \mathrm{a}$ & $2.35 \mathrm{a}$ & $4.51 \mathrm{a}$ & $33.19 \mathrm{ab}$ \\
4 & $11.017 \mathrm{a}$ & $5.11 \mathrm{a}$ & $3.00 \mathrm{a}$ & $9.65 \mathrm{a}$ & $1.78 \mathrm{a}$ & $12.88 \mathrm{a}$ & $2.14 \mathrm{a}$ & $4.53 \mathrm{a}$ & $34.45 \mathrm{ab}$ \\
5 & $8.079 \mathrm{a}$ & $3.31 \mathrm{a}$ & $2.72 \mathrm{a}$ & $10.31 \mathrm{a}$ & $1.52 \mathrm{a}$ & $12.66 \mathrm{a}$ & $1.52 \mathrm{a}$ & $4.75 \mathrm{a}$ & $32.98 \mathrm{ab}$ \\
6 & $10.839 \mathrm{a}$ & $3.75 \mathrm{a}$ & $2.72 \mathrm{a}$ & $10.08 \mathrm{a}$ & $1.51 \mathrm{a}$ & $13.37 \mathrm{a}$ & $1.51 \mathrm{a}$ & $4.53 \mathrm{a}$ & $33.44 \mathrm{ab}$ \\
7 & $9.543 \mathrm{a}$ & $4.47 \mathrm{a}$ & $2.75 \mathrm{a}$ & $10.27 \mathrm{a}$ & $1.71 \mathrm{a}$ & $12.34 \mathrm{a}$ & $1.74 \mathrm{a}$ & $4.84 \mathrm{a}$ & $37.45 \mathrm{a}$ \\
$2010 / 2011$ & $7.01 \mathrm{~b}$ & $7.51 \mathrm{a}$ & $3.03 \mathrm{a}$ & $11.16 \mathrm{a}$ & $2.96 \mathrm{a}$ & $13.98 \mathrm{a}$ & $3.19 \mathrm{a}$ & $3.68 \mathrm{~b}$ & $43.51 \mathrm{a}$ \\
$2011 / 2012$ & $14.36 \mathrm{a}$ & $1.23 \mathrm{~b}$ & $2.21 \mathrm{~b}$ & $8.24 \mathrm{~b}$ & $0.62 \mathrm{~b}$ & $11.37 \mathrm{~b}$ & $0.57 \mathrm{~b}$ & $5.85 \mathrm{a}$ & $19.57 \mathrm{~b}$ \\
\hline $\mathrm{CV}(\%)$ & 22.83 & 62.68 & 13.58 & 7.57 & 52.00 & 8.26 & 46.66 & 13.27 & 13.41 \\
\hline
\end{tabular}

Means followed by the same lower case letter in the column do not differ by Tukey test at $5 \%$ probability of error. ${ }^{*} \mathrm{~T} 1$ : no defoliation, T2: withdrawn the pair of unifoliate leaf the V4 stage of this and the other treatments (T3, T4, T5, T6, T7), T3: removed the first trifoliate at $\mathrm{V} 5$, this and the remainder (T4, T5, T6, T7), T4: withdrawn the second trefoil in $\mathrm{V} 6$, this and (T6 and T7), T5: detached in the third trefoil V7, and this treatment (T6 and T7) T6: detached in the fourth trefoil stage V8 T6 and T7, T7: this latest treatment consisted in the withdrawal of the fifth trefoil stadium in V9.

Table 2. Average results obtained for the interaction effects of stem height (HS), number of branches (NB) and length of branches (LB), number of pod on the main stem (MSP) and grain yield (kg ha ${ }^{-1}$ ) in soybean crops in 2010/2011 and 20112012 (11/10 - 11/12), Frederico Westphalen, 2013.

\begin{tabular}{|c|c|c|c|c|c|c|}
\hline \multirow{2}{*}{$\begin{array}{l}\text { Variable } \\
\text { Treat/Crop }\end{array}$} & \multicolumn{2}{|c|}{$\mathrm{HS}$} & \multicolumn{2}{|c|}{ NB } & \multicolumn{2}{|c|}{ LB } \\
\hline & $10-11$ & $11-12$ & $10-11$ & $11-12$ & $10-11$ & $11-12$ \\
\hline $1^{*}$ & 66.50 a $A$ & 69.96 a A & 1.75 a $\mathrm{A}$ & $0.62 a b B$ & $23.10 \mathrm{abA}$ & $11.27 \mathrm{ab} B$ \\
\hline 2 & $64.00 \mathrm{ab} B$ & 71.26 a A & $1.62 \mathrm{ab} \mathrm{A}$ & $0.36 a b B$ & 14.78 b A & $1.62 \mathrm{ab} A$ \\
\hline 3 & 64.87 a $A$ & 67.85 a $A$ & 2.25 a A & $0.05 a b B$ & 26.25 a $A$ & 2.25 a A \\
\hline 4 & $62.12 \mathrm{ab} A$ & 67.85 a $A$ & $1.62 \mathrm{ab} \mathrm{A}$ & 0.05 b B & 19.93ab A & $1.62 \mathrm{ab} A$ \\
\hline 5 & $61.37 \mathrm{abc} B$ & 71.97 a A & $0.75 \mathrm{cA}$ & $0.43 a b$ A & 13.43 b A & $0.75 \mathrm{cA}$ \\
\hline 6 & 55.75 c B & 75.03 a $A$ & $0.87 \mathrm{bc} \mathrm{A}$ & $0.15 \mathrm{~b} \mathrm{~A}$ & 13.93 b A & $0.87 \mathrm{bc} \mathrm{A}$ \\
\hline 7 & 58.25 bc B & 69.67 a A & $0.50 \mathrm{cA}$ & 1.19 a A & $13.62 \mathrm{~b} \mathrm{~A}$ & $0.50 \mathrm{cA}$ \\
\hline CV(\%) & \multicolumn{2}{|c|}{6.75} & \multicolumn{2}{|c|}{57.53} & \multicolumn{2}{|c|}{46.46} \\
\hline
\end{tabular}

Means followed by the same lowercase and uppercase in the column on the line do not differ by Tukey test at $5 \%$ probability of error. *T1: no defoliation, T2: withdrawn the pair of unifoliate leaf the V4 stage of this and the other treatments (T3, T4, T5, T6, T7), T3: removed the first trifoliate at V5, this and the remainder (T4, T5, T6, T7), T4: withdrawn the second trefoil in V6, this and (T6 and T7), T5: detached in the third trefoil V7, and this treatment (T6 and T7) T6: detached in the fourth trefoil stage V8 T6 and $\mathrm{T7}, \mathrm{T7}$ : this latest treatment consisted in the withdrawal of the fifth trefoil stadium in V9.

For the other variables the removal of the lower leaves during the vegetative period, from the unifoliolates until the fifth leaf caused no change in the yield. Regarding the variables related to the nodes on the plant NPN, RNMS, NRB, NMS, NNB and DBN, these data agree with those of Sperb (2011) who observed that even with the $100 \%$ defoliation there was no difference 
in the number of fertile nodes on the main stem and secondary in stages V6 and V9. However, according to Jiang and Egli (1993), these variables are important in determining the yield potential, since the TP is determined by the relative production of flowers and pods to make, being determined by the number of flowers and the number of nodes reproductive nodes present per plant.

All of these traits who are related with number of pods per plant BP, NPN, RNMS, NRB, NMS, NNB, TP and MSP, values were minors in the agricultural year 2011/2012 (Table 1). This harvest showed low levels of precipitation (Figure 1). Physiological and morphological changes in plants are often induced by adverse environmental conditions such as temperature, water availability, and solar radiation (Embrapa, 2004). According Balardin et al. (2011) water deficit stress is more damaging on the soybean crop, causing extensive damage to the plant development.

Only the lowest pod-bearing node on the main stem and the distance between nodes were higher than the agricultural year 2011/2012. Reductions in lowest pod node can affect the pod harvesting system, resulting in yield losses due harvester's not performing cutting very near the ground. According Peske et al. (2006), the insertion height of the pods is related to a characteristic related to efficiency of collection, together with plant height, level of branching, level of lodging and stem diameter.

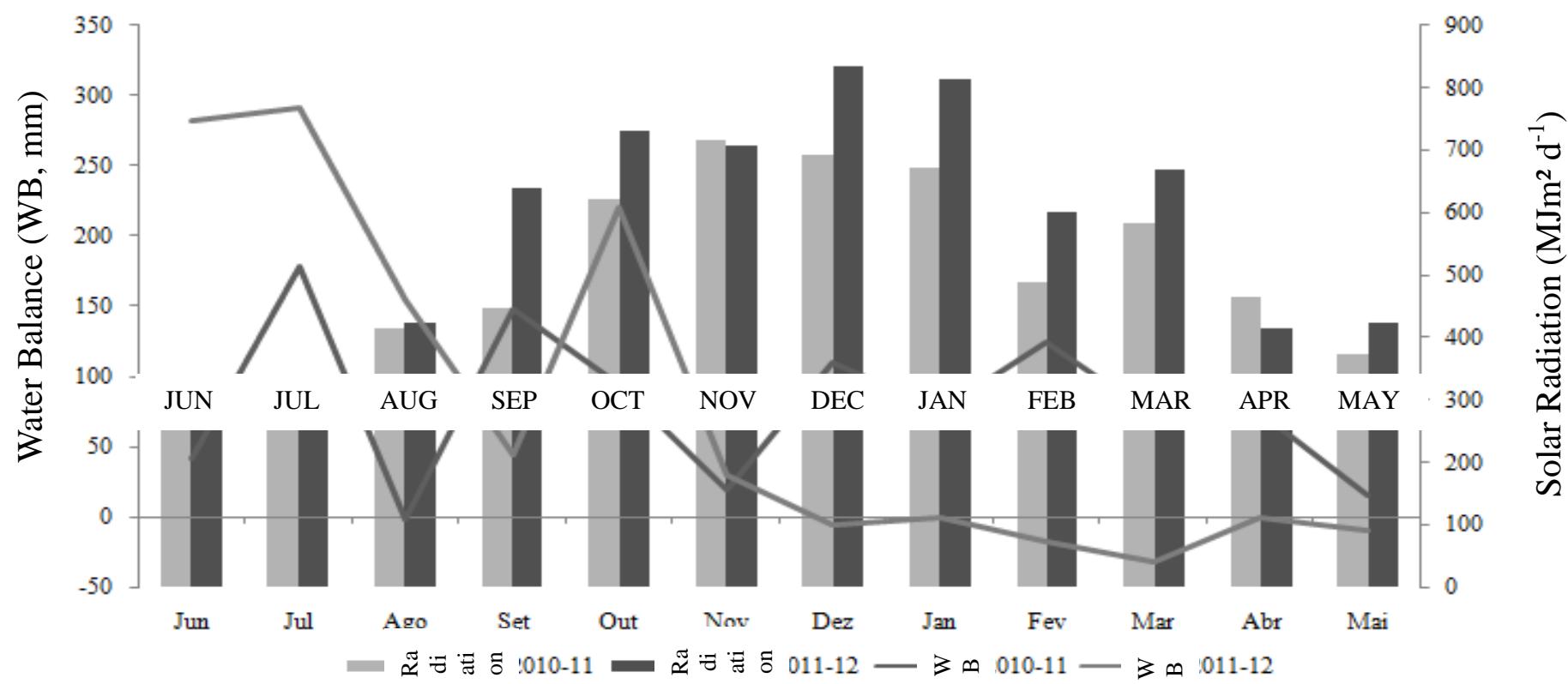

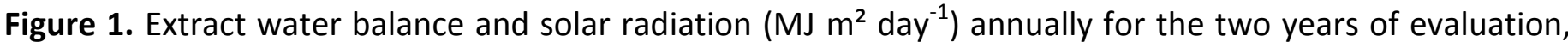
concerning the month of sowing (November) harvest (April), the municipality in Frederico Westphalen. Meteorological data: INMET, Campus Frederico Westphalen - UFSM Calculation method Thornthwaite \& Marther.

With respect to main stem height treatments 6 and 7 differed from other treatments, but not each other. To control the NB is shown with greater compared to treatments NB
5, 6 and 7 for the 2010/11 harvest to $11 / 12$ differences occur between treatment 7 (major) compared to treatments 4 and 6 do not reveal significant differences between the other defoliation treatments. For the length of the 
branches in V6 defoliation (treatment 3) proves to be superior to treatments, 2, 5, 6 and 7 to 2010/11 harvest. For 2011/12 harvest treatment 5 presents greater for the character, differing treatment 4, and do not differ from the others. Anyway both NB and LB show up with variations among the treatments in the two agricultural harvests, possibly the year variation factor has greater influence on these characters than the treatments employed. Diego et al. (1997) in a similar study, demonstrated decrease in the size of the plants, with higher levels of defoliation, and Peluzio et al. (2004) only demonstrated this decrease to $100 \%$ defoliation and from V5.

With respect to main stem height treatments 6 and 7 differed from other treatments, but not each other. To control the NB is shown with greater compared to treatments NB 5, 6 and 7 for the 2010/11 harvest to 11/12 differences occur between treatment 7 (major) compared to treatments 4 and 6 do not reveal significant differences between the other defoliation treatments. For the length of the branches in V6 defoliation (treatment 3 ) proves to be superior to treatments, 2, 5, 6 and 7 to 2010/11 harvest. For 2011/12 harvest treatment 5 presents greater for the character, differing treatment 4, and do not differ from the others. Anyway both NB and LB show up with variations among the treatments in the two agricultural harvests, possibly the year variation factor has greater influence on these characters than the treatments employed. Diego et al. (1997) in a similar study, demonstrated decrease in the size of the plants, with higher levels of defoliation, and Peluzio et al. (2004) only demonstrated this decrease to $100 \%$ defoliation and from V5. In terms of the number of pods on the main stem (Table 3 ) due to the defoliation, one realizes that the TP is superior to treatment to $2010 / 11$ harvest where for the same harvest yield is higher in the treatment 7 compared to 5 and 1 treatments did not differ from the others. For 2011/12 harvest the MSP did not reveal variation for factor defoliation treatment. In relation to income in the same year agricultural treatments 3,5 and 7 are compared to the controls and treatment 6 . Even with the large differences in pod numbers between years, total grain yield was not significantly different. Comparing the two agricultural seasons 2010/11 reveals be superior to the characters MSP and yield. Soybean closes stomatal apertures under water deficit, potentially reducing photosynthesis, these features are often observed in crops conducted one year to another, whose levels of precipitation are contrasting and provide the variability in grain yield (Farias et al., 2007). The positive response to yield (Table 3) with defoliation during the vegetative period was also observed by Parcianello et al. (2004), who attributed the greater fixing pods in the plant. Similarly, Diogo et al. (1997), observed a tendency to increase the productivity with defoliation of 33 and $66 \%$, mainly in the V3 stage. Reichert and Costa (2003) assessed that up to $33 \%$ defoliation in the vegetative stages resulted in no change in yield, in the same way, and Fontoura et al. (2006) found that there was no significant effect of defoliation in vegetative period on the grain yield, but only assessed the stage $\mathrm{V} 9$ within the growing season. Similarly, Peluzio et al. (2004) demonstrated that defoliation of $33 \%$ in all growth stages and up to $66 \%$ by the $\mathrm{V} 5$ results in no effect on productivity, results similar to those found in this work, where defoliation from V4 to V9 provided increases in productivity culture in relation to the control treatment. 
Table 3. Average results obtained for the interaction effects of number of pod on the main stem (MSP) and grain yield $\left(\mathrm{kg} \mathrm{ha}^{-1}\right)$ in soybean crops in 2010/2011 and 20112012 (11/10 - 11/12), Frederico Westphalen, 2013.

\begin{tabular}{cllll} 
Variable & \multicolumn{4}{c}{ MSP } \\
\cline { 2 - 5 } Treat/Crop & \multicolumn{1}{c}{$10-11$} & $11-12$ & $10-11$ & $11-12$ \\
\cline { 2 - 5 } $1^{*}$ & $32.87 \mathrm{c} \mathrm{A}$ & $16.28 \mathrm{a} \mathrm{B}$ & $3616.14 \mathrm{~b} \mathrm{~A}$ & $1676.68 \mathrm{~b} \mathrm{~B}$ \\
2 & $30.25 \mathrm{c} \mathrm{A}$ & $18.41 \mathrm{a} \mathrm{B}$ & $4108.76 \mathrm{ab} \mathrm{A}$ & $2125.92 \mathrm{ab} \mathrm{B}$ \\
3 & $33 \mathrm{bc} \mathrm{A}$ & $15.67 \mathrm{a} \mathrm{B}$ & $3940.75 \mathrm{ab} \mathrm{A}$ & $2625.23 \mathrm{a} \mathrm{B}$ \\
4 & $35.62 \mathrm{~b} \mathrm{~A}$ & $20.34 \mathrm{a} \mathrm{B}$ & $4310.94 \mathrm{a} \mathrm{A}$ & $2012.53 \mathrm{ab} \mathrm{B}$ \\
5 & $37.62 \mathrm{~b} \mathrm{~A}$ & $18.44 \mathrm{a} \mathrm{B}$ & $3621.87 \mathrm{~b} \mathrm{~A}$ & $2671.25 \mathrm{a} \mathrm{B}$ \\
6 & $38.00 \mathrm{~b} \mathrm{~A}$ & $17.98 \mathrm{a} \mathrm{B}$ & $3938.15 \mathrm{ab} \mathrm{A}$ & $1710.81 \mathrm{~b} \mathrm{~B}$ \\
7 & $44.62 \mathrm{a} \mathrm{A}$ & $16.84 \mathrm{a} \mathrm{B}$ & $4278.89 \mathrm{a} \mathrm{A}$ & $2537.51 \mathrm{a} \mathrm{B}$ \\
\hline
\end{tabular}

$\mathrm{CV}(\%)$

12.28

12.77

Means followed by the same lowercase and uppercase in the column on the line do not differ by Tukey test at $5 \%$ probability of error. ${ }^{*} \mathrm{~T} 1$ : no defoliation, $\mathrm{T} 2$ : withdrawn the pair of unifoliate leaf the $\mathrm{V} 4$ stage of this and the other treatments (T3, T4, T5, T6, T7), T3: removed the first trifoliate at V5, this and the remainder (T4, T5, T6, T7), T4: withdrawn the second trefoil in V6, this and (T6 and T7), T5: detached in the third trefoil V7, and this treatment (T6 and T7) T6: detached in the fourth trefoil stage V8 T6 and T7, T7: this latest treatment consisted in the withdrawal of the fifth trefoil stadium in V9.

This positive response in yield may be related to the source-sink relationships in plants. The withdrawal with defoliation to V9 may have represented a reduction in competition for photoassimilates, but mainly for soil nutrients and water between plant organs. The largest volumes of nutrients to be passed for the maintenance of reproductive structures, physiological mechanisms by own culture, in contrast to the leaves, leading to decrease in the abortion of flowers and vegetables and possibly the largest grain filling, which was reflected in increased yield. According to Bueno et al. (2010), the effect of defoliation in vegetative stages usually has little or no effect on grain yield, because the soybean plant recovery present in this period, with the issuance of new leaves, and in addition to this feature the culture still has area leaf in excess, which favors maximum solar radiation interception by the leaves remnants.

In a study of Haile et al. (1998), with cultivar of indeterminate growth habit argues that the loss of leaf area increased the ability of light interception by the plant canopy openness and caused delay in leaf senescence. These two changes are translated into higher photosynthetic capacity for a longer period of time, which contributes to the understanding of the results found in this study for higher grain yield levels of defoliation V4 to V9 in two agricultural respectively.

The results did not corroborate with others who claim that soybean has monocarpic senescence (Munné-Bosch and Alegre, 2004), requiring energy coming from the senescence of old leaves for their vegetative and reproductive development. In this study as defoliation was initiated in the V4 stage the leaves did not have characteristics of early senescence and all the energy contained ceased to be reused by plants.

Analyzing the variables number of pod on the main stem and grain yield under the guise year of cultivation in the agricultural year 2010/2011 it obtained the highest results, which is attributed to better water conditions found in that year (Table 2).

Small intensities of defoliation on soybean do not translate into loss of productivity. Studies like this, however, bring more specific results for the cultivar studied, and may extend in part to similar cultivars, because the architecture of plants to be decisive in sensitivity to defoliation, 
and for both, new study should be conducted with cultivars different sizes and architectures.

\section{CONCLUSIONS}

For the cultivar used and other conditions established in this study, it is concluded:

The defoliation during the vegetative stages, until the levels tested did not influence the first pod insertion, number of pod on branches, number of pod per node, number of reproductive nodes on the main stem, number of nodes reproductive branches, total number of nodes in stem, total number of nodes the branches, distance between nodes and number of pods per plant.

The defoliation did not affect grain yield for the two agricultural harvests evaluated.

\section{REFERENCES}

Balardin RS, Silva FDL, Debona D, Dalla Corte G, Dalla Favera D and Tormen NB (2011) Tratamento de sementes com fungicidas e inseticidas como redutores dos efeitos do estresse hídrico em plantas de soja. Ciência Rural, 41: 1120-1126.

Barros HB, Santos MM, Peluzio JP, Rocha RNC, Silva RR and Vendrusculo JB (2002) Desfolha na produção de soja (Glycine Max "M-SOY 109"), cultivada no cerrado, em Gurupi - TO, Brasil. Bioscience Journal, 18: 5-10.

Bueno AF, Batistela MJ and Moscardi F (2010) Níveis da desfolha tolerados na cultura da soja sem a ocorrência de prejuízos à produtividade. Circular Técnica 79, ISSN 2176-2864, 12p.

Conab, Companhia Nacional de Abastecimento. 2012 Acompanhamento de safra brasileira: grãos, décimo primeiro levantamento, agosto 2012. Brasilia:

Conab.<http://www.conab.gov.br/OlalaCMS/uplo ads/arquivos/12_08_09_10_58_55_boletim_port ugues_agosto_2012.pdf. Acesso em 12 de agosto de 2013.>
Costa MAG, Balardin RS, Costa EC, Grützmacher $A D$ and Mauro Silva, MTB (2003) Níveis de desfolha na fase reprodutiva da soja, cv. Ocepar 14, sobre dois sistemas de cultivo. Ciência Rural, 33: 813-819.

Diogo AM, Sediyama T, Rocha VS and Sediyama CS (1997) Influência da remoção de folhas, em vários estádios de desenvolvimento, na produção de grãos e em outras características agronômicas da soja. Revista Ceres, 44: 272-285.

Embrapa. 2004 Tecnologia de produção de soja. Sistemas de Produção 5. ISSN 1677-8499. Londrina, $239 \quad$ p. <http://pt.scribd.com/doc/5786460/Tecnologiade-Producao-de-Soja>. 12 de agosto de 2013.

Farias JRB, Nopomuceno A and Neumaier N (2007) Ecofisiologia da soja. Circular Técnica. ISSN 1516-7860. Londrina, Setembro.

<http://www.cnpso.embrapa.br/download/cirtec /circtec48.pdf>. 12 de agosto de 2013.

Fehr WR and Caviness CE (1977) Stages of soybean development. Ames: lowa State University, 12p. (Special Report, 80).

Fontoura TB, Costa JA and Daros E (2006) Efeitos de níveis e épocas de desfolhamento sobre o rendimento e os componentes do rendimento de grãos da soja. Scientia Agraria, 7: 49-54.

Haile FJ, Higley LG and Specht JE (1998) Soybean cultivars and insect defoliation: Yield loss and economic injury levels. Agronomy Journal, 90: 344-352.

Higley, L. G. New understandings of soybean defoliation and their implications for pest management. p. 56-65. In L. G. Copping, M. B. Green, and R. T. Rees (eds.) Pest Management of Soybean. Elsevier Science Pub., Amsterdam, The Netherlands, 1992. p. 56-65. 
Jiang $\mathrm{H}$ and Egli DB (1993) Shade induced changes in flower and pod number and flower and fruit abscission in soybean. Agronomy Journal, Madison, 85: 221-225.

Mundstock CM and Thomas AL (2005) SOJA: Fatores que afetam o crescimento e o rendimento de grãos. Universidade Federal do Rio Grande do Sul, Porto Alegre, 30p.

Munné-Bosch S and Alegre L (2004) Die and let live: leaf senescence contributes to plant survival under drought stress. Functional Plant Biology, 31: 203-216.

Parcianello G, Costa JA, Pires JLF, Rambo L and Saggin K (2004) Tolerância da soja ao desfolhamento afetada pela redução do espaçamento entre fileiras. Ciência Rural, 34: 357 364.

Pedigo, L. P., Hutchins, S. H., \& Higley, L. G. (1986). Economic injury levels in theory and practice. Annual review of entomology, 31(1), 341-368.

Peluzio JM, Barros HB, Brito EL, Santos MM and Silva RR (2004) Efeitos sobre a soja do desfolhamento em diferentes estádios fenológicos. Revista Ceres, 51: 575-585.

Peske ST, Lucca-Filho AO and Barros ACSA (2006) Sementes: fundamentos científicos e tecnológicos. 2.ed., Pelotas: Ed. Universitária/UFPel, p.227-240.

Reichert JL and Costa EC (2003) Desfolhamentos contínuos e seqüenciais simulando danos de pragas sobre a cultivar de soja BRS 137. Ciência Rural, 33: 01-06.

Ribeiro ALP and Costa EC (2000) Desfolhamento em estádios de desenvolvimento da soja cultivar BR16 no rendimento de grãos. Ciência Rural, Santa Maria, 30: 767-771.
Sediyama T, Pereira MG, Sediyama CS and Gomes JLP (1996) Cultura da soja. Viçosa, MG, 75p.

Sperb DF (2011) Alterações na relação fontedemanda no rendimento de grãos e crescimento da soja. Curso de Pós-graduação em Agronomia, Universidade Federal do Rio Grande do Sul. 81p. Dissertação (Mestrado em Fitotecnia).

Thornthwaite CW and Mather JR (1955). The water balance. Publications in Climatology. New Jersey: Drexel Institute of Technology, 104p. 